\title{
The Leadership Element Supporting on Evaluation Culture of Sustainable Capacity Building for Decentralization Project in Central Tapanuli District
}

\author{
Tunggul Sihombing \\ Department of Public Administration Science, Faculty of Social and Political Universitas Sumatera Utara \\ Medan, Indonesia \\ tlumbantoruan@yahoo.co.id
}

\begin{abstract}
Evaluation capacity building has become a hot topic of conversation, activity, and study within the evaluation field. The evaluative culture has studied from a perspective of the characteristics of evaluative culture leadership through evaluative actions of commitment, information on the outcomes needed, and responsibility of sustainable capacity building for decentralization project in Central Tapanuli District, The North Sumatera Province in Indonesia. the members of monitoring and evaluation team, the leaders of Satuan Kerja Perangkat Daerah (SKPD), and their staffs in Central Tapanuli Regency, The result of study found that the evaluative leadership action of government local work unit on Central Tapanuli Regency, The North Sumatera Province in Indonesia got low on their commitment, they didn't showe any appreciation of output information, unclear of role and responsibility, in such a way that evaluation culture of Sustainable Capacity Building for Decentralization still weak.
\end{abstract}

Keywords : Evaluation culture, commitment, information, responsibility

\section{INTRODUCTION}

Evaluation capacity building has become a hot topic of conversation, activity, and study within the evaluation field. Seeking to enhance stakeholders' understanding of evaluation concepts and practices, and in an effort to create evaluation cultures, organizations have been implementing a variety of strategies to help their members learn from and about evaluation [1]. Developing and maintaining an evaluative culture in an organization is often seen as key to building more effective results management and evaluation approaches. On an ongoing basis, there needs to be a climate in the organization where evidence on performance is valued, sought out and seen as essential to good management. Without such a climate, adherence to systems and procedures can dominate attitudes towards results management and evaluation [2].

In general, there are four key steps in planning a sustainable process of change towards an organisational evaluation culture:

(1) Assessing organisational readiness;

(2) Creating the climate for cultural change;

(3) Engaging staf; and
(4) Implementing and sustaining an evaluation culture [3].

Traditionally, there are three key models of evaluation are available to human service organizations. They are: organizations engage an external evaluator such as a university academic or evaluation consultant to carry out specific evaluation projects, organizations develop their internal capacity and capacity to coordinate and manage evaluation projects; and organizations use a combination of both internal and external to fulfil organizational needs and funding requirements in a hybrid model [4].

\begin{tabular}{|l|l|}
\hline 1 & Assess organisational readiness \\
\hline $\mathbf{2}$ & Plan and create the climate for cultural change \\
\hline $\mathbf{4}$ & Engage staff and communicate the vision \\
\hline & Implement with strategies for sustainable change \\
\hline
\end{tabular}

Figure 1. Four steps in creating an organizational evaluation culture [3].

Without doubt, a key advantage of using external consultants and academics is that evaluations are often seen as independent and objective, a strategic benefit in an increasingly competitive sector in which evidence from evaluation is being considered in decision-making processes by government and funders more than ever. The present paper reported the work of the author as an external consultant and academic on the evaluative culture from a perspective of the characteristics of evaluative culture leadership through evaluative actions of commitment, information on the outcomes needed, and responsibility of sustainable capacity building for decentralization project in Central Tapanuli District, The North Sumatera Province in Indonesia [5], [6].

\section{METHODS}

This study used a qualitative method with all informants were the members of monitoring and evaluation team, the leaders of Satuan Kerja Perangkat Daerah (SKPD), and their staffs in Central Tapanuli Regency, The North Sumatera 
Province in Indonesia. Data collection methods used were interview, observation, and documentation. Data then analyzed according to the categorization of commitment evaluative action, needs of information on the results, and the role and responsibility in the evaluative culture of sustainable Capacity Building for Decentralization (SCBD) Project obtained during interview, observation, and documentation study.

\section{RESULTS AND DISCUSSION}

The results of SCBD Project activities in Central Tapanuli Regency, The North Sumatera Province in Indonesia could be made as a basis of consideration for making policies in building the capacity of government to enhance its public services. In fact, the application of the results of SCBD Project continuously or sustainably is intended as an evaluation culture. The results of interviewed with an informant disclosed that "education and training (diklat) activity for those civil servants-former participants of SCBD diklat must be personally beneficial because it may add on their knowledge, but institutionally it has not been seen". Moreover, other informant stated that: "Particularly at Bappeda (Regional Revenues Agency) office of Central Tapanuli Regency, I could tell that information on the performance of SCBD Project activities might be useful for the employees in accomplishing their main duties and functions, such as those activities of diklat on goods/services procurement, legal drafting, regional economic development, etc." From the result of interviews as disclosed by the informants, it could be known well that the results of SCBD Project activities have been significantly valuable for Bappeda's civil servants in implementing their daily duties. Moreover, it was also found from other informant that: "The responses of SKPD officers in Central Tapanuli Regency varied on the application of the results of SCBD activities. Some supported and some didn't on a reason that SCBD Project wasn't their duty but rather Bappeda's. Other weakness was that SKBD officers in Central Tapanuli Regency have been rotated so frequently and even there were heads of agency who held their job for only 5 (five months) or even non-job. Thus, they couldn't focus in implementing the results of SCBD activities and in measuring the enhancement of capacity or asking a follow-up development of the implementation of the information on the evidence of SCBD Project activities"

It is very clearly findings that the responses of the SKPD officers in Central Tapanuli Regency were mixed, some supported and some didn't at all on a reason that SCBD Project was Bappeda's duty. Those SKPD heads who didn't support it perceived that SCBD Project activities weren't their duty. On the other side, such perception received little support due to the frequent rotation of SKPD heads so that they lacked of focus in applying the results of SKPD Project. From the information that the informants conveyed, it can be interpreted that the SKPD heads didn't demonstrated a leadership in management and high commitment, didn't played a role and responsibility for managing the results of SCBD Project, were inconsistent in acting by an evaluative culture way, and didn't implement what their head of Regional Government determined, except for by Bappeda head. This is substantiated by the results of another informant, who stated as follows:

"Concerning the support of leadership, I feel nothing. Take, as an example, goods/services procurement. I hadn't been involved in a committee, but I was punished with a sanction by the leader, whereas what I did just to assist the committee in overcoming the problems they had been faced with. Clearly, the leader didn't commit and wasn't fair; he didn't assign a clear role and responsibility to the committee; he didn't care of the results achieved correctly by the committee; he ignored the capacity of his subordinates"

More obviously, it can be asserted that the leaders of SKPDs in Central Tapanuli Regency didn't evenly ask for information on the result of SCBD Project even though it was of high significance in preparing planning, budgeting, and reporting in attempt to implement a better project, better services, and better performance. These facts indicated that the support of SKPD leaders in developing evaluative culture was low. They were less responsive to the performance of Bappeda agency and didn't evaluate themselves as a part of management in general. The capacity of evaluative actions of the SKPD leaders has little benefit in developing evaluative culture in the implementation of SCBD Project outcomes. Moreover, when the researcher asked a question to one of the informants as an evaluator of monitoring and evaluation team member, the informant responded as follows: "SCBD Project, the financial source of which is from the APBD (local budget) of Central Tapanuli Regency, was over in 2013 ago. Concerning its implementation, it depended on the leader of each SKPD, whether or not to implement it. In fact, there were some SKPDs which are keeping status quo, e.g., BKD and Integrated Service Office, whereas all SCBD activities are highly needed ... once a SCBD Project report was finished, there was nothing to do at all. No division or unit followed up it".

It could also be said that the leaders didn't optimally support the implementation of the results of SCBD Project activities, weren't consistent in managing the results of SCBD Project activities, weren't consistent in acting by evaluative culture, and didn't implement what had been agreed upon. They didn't committee to implementing the results of SCBD Project activities, didn't practice a clear role and responsibility in managing the results, missed the outcomes of capacity building, and didn't need any evidence of the better outcomes they prioritized. The leaders' actions weren't optimal in supporting the development of an evaluative culture that provide hopes on the management of challenging-but-hard-toimplement results so that the changes expected in conformity with SCBD Project and empirical evidence were still far from the expected. The information told above explains that the leaders of SKPDs in Central Tapanuli Regency haven't yet been of the same perception on the implementation of the results of SCBD Project and thus some of them supported and others didn't. The latter said that SCBD Project wasn't their 
responsibility but rather Bappeda's. Based on the description of informants above on the support of leadership to the development of SCBD Project evaluative culture, it could be understood that leadership element could be valuable in developing an evaluative [2], [3]. If the SKPD leaders show a high leadership commitment, supply data on results, and assign clear role and responsibility in managing the results. Leadership actions should use the evidence of the results of SCBD Project activities in developing evaluative culture, or more clearly, a leadership that shows the need of consistence to the management of results, including consistent communication on the management of results and consistence in acting by evaluative culture and in implementing what have been agreed upon.

Therefore, based on these information, it could be said that in the implementation of information on performance or empiric evidences of SCBD Project in helping the development of project evaluative culture where the support of the leadership element of SKPDs was needed in Central Tapanuli Regency has not been followed by a uniform perception among the leaders. Some of them did support it but some didn't or supported it halfheartedly and another didn't at all. In line with the previous authors [2], [1], [7]. The leaders of SKPDs in Central Tapanuli Regency should realize that leadership is a most important factor in an organizational evaluative culture. They have to demonstrate that they are the leaders who are capable of making changes.

\section{CONCLUSION}

The leadership support of the leaders of all SKPDs in Central Tapanuli Regency, The North Sumatera Province in Indonesia showed a low leadership commitment evaluative action; they didn't have information on increases in the measurement and capacity of results management; they didn't ask information on the outcomes achieved in the availability of the data of results; they neither assigned nor communicated clearly the roles and responsibilities in an evaluative culture, and the characteristics of the evaluative culture level of SCBD Project in Central Tapanuli Regency, The North Sumatera Province in Indonesia was at a weak evaluative culture level. There was also no found an evaluation unit or team which was instituted and responsible for instilling evaluative actions in daily working practices for the sake of the development of an evaluative culture which may determine the performance of public administration.

\section{ACKNOWLEDGMENT}

The author are sincerely thanks to his colleague, Prof. Yusuf L. Henuk, Ph.D (yusufhenuk62@live.com) from University of Sumatera Utara for his critical reading and editing of this manuscript.

\section{REFERENCES}

[1] Preskill, H. and Boyle, S. 2008. A Multidisciplinary Model of Evaluation Capacity Building. American Journal of Evaluation, 29 (4December): 443-459.

[2] Mayne, J. (2008). Building an Evaluative Culture for Effective Evaluation and Results Management. ILAC Working Paper 8, Rome, Institutional Learning and Change Initiative.

[3] McCoy, A., Rose, D., Connolly, M. 2013. Developing evaluation cultures in human service organisations. Evaluation Journal of Australia, 13(1): $15-20$

[4] Carman, J.G. and Fredericks, K.A. 2010. Evaluation capacity and nonprofit organizations: is the glass half-empty of half-full. American Journal of Evaluation, 31 (1): 84 - 104.

[5] Sihombing, T. dan Pardede, R.H. 2011a. Ringkasan Eksekutif Laporan Akhir. Proyek SCBD Kabupaten Tapanuli Tengah, Bappeda, Pandan.

[6] Sihombing, T. dan Pardede, R.H. 2011b. Laporan Akhir. Proyek SCBD Kabupaten Tapanuli Tengah, Bappeda, Pandan.

[7] Sihombing, T. 2016. Public Service Innovation and Reform Towards Good Local Governance. Global Journal of Politics and Law Research, February, 4 (1): 64-72.. 